\title{
Education of Entrepreneurship and Creative Economy in Women Independence Based on The Center of Community Learning Activities Program
}

\author{
*Nuraini Asriati, University of Tanjung Pura Pontianak, Indonesia, nuraini.asriati@fkip.untan.ac.id \\ Munawar Thoharudin, University of Tanjung Pura Pontianak, Indonesia, munnawar.thoha99@gmail.com \\ Jumardi Budiman, University of Tanjung Pura Pontianak, Indonesia, jumardib@fkip.untan.ac.id \\ ${ }^{*}$ Corresponding Author
}

\begin{abstract}
This study aims to provide entrepreneurship education to women based on the creative economy empowerment model to create women's independence in the context of poverty alleviation. Entrepreneurship and creative economy education is carried out through the Community Learning Activity Center (CLAC) program, by taking samples and data from the Marga Jaya CLAC group, Rasau Jaya District, Kubu Raya Regency. This study used the Research and Development or R\&D method using 100 research subjects who were members of the Marga Jaya CLAC group, while the object of research was the creative economy model of women in the Rasau Jaya transmigration area. From the research results, it can be concluded that some women members of the Marga Jaya CLAC group strongly agree with the existence of creative economy education, this can be seen from a questionnaire about ten entrepreneurial behaviors where most of them agree with these ten behaviors. From the research, it was also found that the Community Learning Activity Center (CLAC) can be a medium for creative economy education using participatory skills education methods.

Keywords: Creative Economy, Poverty, Entrepreneur, Women's Independence, CLCA

Received: 03.11.2020 Accepted: 09.12.2020

Published: 05.01.2021
\end{abstract}

\section{INTRODUCTION}

Poverty is not a new issue, and many studies have even tried to solve this problem (Azariadis \& Stachurski, 2005), but in reality, poverty still shackles the lives of most of the Indonesian population, mostly rural and transmigration areas. Poverty is a multifaceted, multi-dimensional, and integrated phenomenon. This phenomenon has become a concern, issue, and global movement that is human in nature (Tsui, 2002).

Various concepts of women and rural issues are often discussed. However, the idea of both is never separated from the term poverty (Alcalde, 2010). The point of poverty often marginalizes gender issues into something that is considered normal so that this phenomenon is evident in micro studies, especially in the provision of funds and business networks (McLanahan \& Kelly, 2006).

Based on BPS data, there are 37.17 million people or $17.75 \%$ of the number of poor people from Indonesia's total population. Meanwhile, based on 2014 data, the poor people in the area of Kubu Raya was $5.45 \%$. This data is based on a macro approach to consumption per capita and a poverty line of IDR 286,612 per capita per month.

The Rasau Jaya area is a transmigration area with the community's potential for land and business ventures. Rasau Jaya after its expansion from Productive Economic Business Activities includes all activities related to efforts to increase the capacity / economic empowerment of community members, for example, CLAC business units, Business Study groups, community business development, community business cooperation and networks, efforts increase in community productivity, and the creation of new jobs.

The potential of Rasau Jaya is based on 1) geographical location, namely: on the map 109.14 30.83 "19026 30.65" East Longitude and 00.1130 .39 "- 00.19 39.42" South Latitude; 2) The administrative location of the Independent transmigration area (ITA) location is administratively located in the District of Rasau Jaya; 3) The area of the prospective ITA location is estimated to be around 85,238 hectares with a population of about 52,755 people (BPS.2006) spread over 11,157 hectares of the Kec. Rasau Jaya, with a population of 
20,806 people; 4) Accessibility and Physical Conditions from Pontianak to Rasau Jaya can be reached by road for 45 minutes by regular public transportation; 5) The topography of the prospective KTM location is relatively flat with an average land slope of 0-3\% (Hutajulu, 2015).

The Kubu Raya Regency's development strategy includes six fields: human resource development, economic development, infrastructure development, government development, environmental development, and socio-cultural development, with priority programs on poverty alleviation, resource quality improvement. Education and health quality improve infrastructure quality and quantity, enhancing government facilities and infrastructure (Yurisinthae \& Dolorosa, 2015).

However, none of the poverty criteria above clearly state the causes of poverty itself. Regarding the causes of poverty, it is necessary to conduct a more in-depth study through scientific research. This is important because each region has a different background to poverty (Ravallion, 2007). This difference is also significant to underline in determining poverty reduction strategies in the form of local policies through community empowerment (Hulme \& Shepherd, 2003).

CLAC entrepreneurship is not a new discourse launched, this discourse has been promoted and socialized for a long time, but some CLAC has not gone that way. About 90 percent of the illiterate population are of productive age and are in weak economies. Meanwhile, CLAC parameters include: 1) Community Participation; 2) Benefits for Society (Impact); 3) Program Quality and Relevance; and 4) Independence and Sustainability of the Institution (Sustainability). Meanwhile, the CLAC characters are 1) Concern for the less fortunate (less well off); 2) Independence in organizing; 3) Togetherness in progress; 4) The meaning of each program and activity; 5) Partnership with all parties who wish to participate and contribute; 6) Flexibility of programs and operations; and 7) Continuous self-renewal (Saludung, 2009).

Poverty is the main problem of development, which is complex and multi-dimensional. Poverty is not only an economic dimension but also social, cultural, political, and even ideological (Basuki \& Presetyo, 2007). Chambers (1983), as quoted by Soetrisno (1995), argues that the essence of the poverty problem lies in the deprivation trap. Deprivation traps consist of five disadvantages that surround the life of a low-income family, namely (1) poverty itself; (2) physical weakness; (3) alienation; (4) vulnerability, and (5) helplessness (Jakson, 1996).

According to statistical reports (BPS, 2014), the poverty rate in Kubu Raya, the number of people living below the poverty line is 29.47 million people (5.54\%). To alleviate poverty, the direction of poverty reduction policies can be carried out through integrated business service centers that are oriented towards the entrepreneurial empowerment of CLAC members.

The creative economy is an economic concept in the new financial era, which intensifies information and creativity by relying on ideas, knowledge, skills, and talents, rather than human resources (Dodd, 2012). This productive and independent creative economic activity is directed at improving four aspects, namely increasing productivity, added value, quality of work, and competitiveness of small businesses (Sarkis et al., 2009). High productivity reflects high competitiveness, and increased competitiveness can generate high economic growth (Poutanen \& Kovalainen 2017). The creative economy is a concept that develops based on creative assets that can help economic growth (Anthopoulou, 2010).

Thus, researchers are interested and consider it essential to research a starting point to contribute to CLAC SMEs as a policy solution by developing productive, creative economic models and independent women who can build a business system and leverage or business competitiveness so that CLAC resources can be synergized between the government. Central, regional, banking, non-bank, training center, and business practitioners. With the development of a productive, creative economy system and women's independence, it means building synergy and integration of potentially abundant resources that impact member business actors' growth.

\section{LITERATURE REVIEW}

\section{Concept of Women in Poverty}

Various conceptual issues of women and rural areas are often discussed. However, the second concept is never separated from the term poverty. The problem of poor women is not only related to the inequality of gender relations between men and women but imbalance with power between the poor and the elite (Hackett \& Betz, 1981; Subiyantoro, 2005).

For poor women, the problem of poverty often marginalizes gender issues into something that is considered normal so that this phenomenon is evident in micro-studies (Moser, 1989). Efforts to reduce 
poverty need to be balanced with public awareness programs. Moreover, one thing that is often overlooked is the feminist dimension and gender inequality (Neysmith \& Reitsma-Street, 2005). Wherever poverty always shows the face of women in front. Many contemporary researchers reveal that women are still the savior valve for the family economy in a low-income family. There are at least four roles for poor women in the family. First, as the manager of family finances; Second, as the person in charge of all domestic work; Third, as the breadwinner of the family; Fourth, as a virtual social network node in terms of the social transfer, especially during critical and crisis times (Basuki \& Prasetyo, 2007). Women's empowerment includes three things: (1) capacity building means building women's capacities; (2) cultural change, namely cultural changes in favor of women; (3) structural adjustment is a structural adjustment in favor of women. Empowerment efforts are directed at achieving community welfare through gender equality. The analysis criteria used in this method consisted of 5 (five) criteria, namely: 1) welfare; (2) access; (3) awareness; (4) participation; and (5) control.

According to Yulia Indrawati (2003), women who can be identified as poor women consist of three groups. First, groups of women who work in the informal sector. Second, the group of women who do not work but have husbands who work as casual laborers. Third, elderly female farmworkers without siblings and children (widows who do not work).

Another problem in women's poverty is the limited space for participation in decision-making, especially women farmers, fishermen, laborers, and micro-entrepreneurs. This concept is defined more as a workplace with a limited community. More than half of the poor in developing countries are women (Whitehead, 2003).

From a gender perspective, the concept of poverty is considered more appropriate to explain gender injustice due to women's lack of access and control over decision-making that is important, and that significantly affects life. Therefore, women are always considered the poorest. (Basuki \& Prasetyo, 2007).

It is concretely stated that poor women are the most vulnerable group because of their subordination due to their position as the inferior group, even though women's investment is considered a more effective way to improve welfare (World Bank, 1999).

Soekartiwi (1993), qualitatively, the characteristics of the low area). The production exchange rate of the poor is low. b) The quality of the resources owned is low; c) Low labor productivity (low education, mastery of technology, and information). d) Limited capital; e) Low-income level, and f) Low level of participation in development. However, none of the poverty criteria above clearly state the causes of poverty itself. Regarding the causes of poverty, it is necessary to conduct a more in-depth study through scientific research. This is important because each region and each ethnic group has a different background to the causes of poverty. It is also essential to underline this difference in determining the poverty alleviation strategy in question. According to Suprapto (2003), there are at least three approaches to understanding poverty in society, namely a cultural approach, a structural approach, and a natural approach. This can be seen from the calculation of life expectancy, student enrollment rates, literacy rates, and real GDP per capita for women. As an illustration, the explanation above can be seen from the following table:

Table 1. Index and Facts of Poverty of Women in Indonesia

\begin{tabular}{|c|c|c|}
\hline Index & Facts & Source \\
\hline Female live expectancy & $\begin{array}{l}\text { The maternal mortality rate is } 307 \\
\text { per } 100,000 \text { live births }\end{array}$ & $\begin{array}{l}\text { Demographic } \\
\text { Survey } \\
\text { and } \\
\text { HealthIndonesia } \\
\text { (SDKI) }\end{array}$ \\
\hline female literacy rate & There are $82 \%$ & $\begin{array}{l}\text { Human } \\
\text { Development } \\
\text { Report (HDR) }\end{array}$ \\
\hline $\begin{array}{l}\text { Female } \\
\text { Participation }\end{array}$ & $\begin{array}{l}\text { the participation of female students who enter } \\
\text { Primary School is } 49 \% \text {, Junior High } 46 \% \text {, High } \\
\text { School } 41 \% \text { and College } 33 \%\end{array}$ & CENSUS \\
\hline $\begin{array}{l}\text { Educational Relevance } \\
\text { Violence }\end{array}$ & Low education is a significant factor in violence & LBH-APIK KALBAR \\
\hline
\end{tabular}




\begin{tabular}{|l|l|l|}
\hline Women,s Income & $\begin{array}{l}\text { Working women are considered additional, not the Marriage Law } \\
\text { main breadwinners }\end{array}$ \\
\hline $\begin{array}{l}\text { Labor } \\
\text { Discrimination }\end{array}$ & $\begin{array}{l}\text { Market } \\
\text { ef the } 51 \% \text { women of productive age, only 37.2\% } \% \text { ILO market in the labor force }\end{array}$ \\
\hline Head of Female Household & $\begin{array}{l}\text { Every } 10 \text { households, } 10 \% \text { are headed by women BPS } \\
\text { and this figure is that } 80 \% \text { of household heads are } \\
\text { widows and } 60 \% \text { are not / have not attended } \\
\text { school, and } 40 \% \text { are illiterate }\end{array}$ \\
\hline Poor Household & $\begin{array}{l}\text { There are } 7.87 \text { million poor households with aBPS } \\
\text { composition of } 37.5 \text { million, of which women head } \\
0.96 \text { million }\end{array}$ \\
\hline
\end{tabular}

Source: Human Development Report (2004)

\section{Creative Economy Concept}

The creative economy is a concept that develops based on creative assets that have the potential to help economic growth (Ismail, 2019). The creative economy can increase income for the community, create jobs and economic value from export activities, which at the same time also help promote socio-cultural diversity and develop human resources (Setyaningsih et al., 2012).

Then the Creative Economy is also able to strengthen economic, cultural, and social aspects that can interact well with technology, intellectual activities, and tourism destinations (Sullaida \& Ahyar, 2017). The creative economy is a knowledge-based economy with the dimensions of developing cross-sectoral relationships at both the macro and micro levels within the overall economic activity (Potts, 2009).

From the above definitions, it can be concluded that the concept of the Creative Economy is an economic concept in the new economic era that intensifies information and creativity by relying on ideas and stock of knowledge from Human Resources (HR) as the main production factor in their economic activities (Woldie \& Adersua, 2004).

The creative economy's vision and mission in 2025 can be realized by the synergy of foundations, pillars, and actors as elements of the creative economy building model. The five main pillars that must be strengthened in developing creative industries are (1) Industry, namely a collection of companies engaged in the creative industry; (2) Technology, namely an enabler for realizing individual creativity in the form of real works; (3) Resources, namely input other than individual creativity \& knowledge required in the creative process, for example, natural resources, land; (4) Institution, namely the social order (norms, values, and laws) including industry associations, professional associations, and other creative communities; and (5) Financial Intermediary, namely financial intermediation institutions. The main actors involved in developing the creative economy:

a. Intellectuals, namely people who are primarily concerned with seeking satisfaction in cultivating art, science, the desire to apply knowledge, and transmitting it, including

b. Business, namely business actors capable of transforming creativity into economic value

c. Government, namely the government as (1) Catalyst \& Advocacy; (2) Regulator; (3) Consumers, investors, and even entrepreneurs; and (4) Urban Planner can enable the creative industry to grow and develop.

\section{Concept of Community Learning Activity Center (CLAC)}

Community Learning Activity Center (CLAC) is a community-based institution (Community Based Institution) CLAC initiative of the community itself which comes from an awareness of the importance of improving the quality of life through transformational and learning processes.

CLAC in its entirety and opens perspectives and insights and steps that can be taken in further development. The implementation and development and sustainability of CLAC are entirely the responsibility of the community itself. The performance of CLAC must be based on and pay attention to the potential of a community and following the local community needs. 
The goal of CLAC in a community is to improve the quality of life of that community in a broad sense. Understanding the quality of life of a community is very much determined by the values that live and are believed by that community. The quality of life will cover a comprehensive dimension as wide as the dimension of life itself. It starts from the spiritual, social, economic, health, mental and personality dimensions, art, and culture, etc. Some communities only highlight one or two dimensions. While other dimensions are not given much attention, some communities try to see all dimensions' importance. Some communities consider a particular dimension to be the main one, while other communities even pay less attention to this dimension. To obtain a concept of quality of life that is generally accepted by various diverse communities, several ideas such as the Human Development Index were developed.

In line with the objectives of CLAC, namely the realization of an increase in the quality of life of the community, where the dimensions of the quality of life are vast, the field of CLAC activities includes three areas of activity, namely the field of learning activities, the field of productive economic business activities (business activities) and the field of development activities. Community (community development activities) (Pramuji, 2010). According to the Ministry of National Education (2010), CLAC parameters consist of: a). Community participation (Community participation) One measure of the progress of a CLAC is the quality and quantity of community participation. The higher the level of community participation in a CLAC, the more it will be seen in every management process, planning, organizing, implementing, and controlling. b) Benefits for the community (Impact) The next parameter to measure the level of progress of a CLAC is the benefit for the community. This contribution can increase knowledge of community members, increase skills, improve behavior, increase income, create jobs, create harmony, and others. c). Program quality and relevance; To assess the programs' quality and relevance, it is necessary to pay attention to inputs, processes, and outputs in program implementation. Many measurement models have been developed to measure the quality and relevance of the learning programs that have been implemented. d) Independence and sustainability of the institution.

The CLAC character shows the values that animate all CLAC activities. To build a good CLAC, the nature of the CLAC must also be formed and strengthened. According to the Ministry of National Education (2010) the seven characteristics that CLAC must have include: (1) Concern for those who are more disadvantaged, (2) Independence in implementation, (3) Togetherness in progress, (4) The meaning of each program and activity, (5) ) Partnership with all parties who wish to participate and contribute, (7) Flexibility of programs and operations, (8) Continuous self-improvement.

\section{METHOD}

This research is a type of research and development (R\&D). The subjects of this research are 100 members of CLAC Marga Jaya who have productive businesses in processing organic fertilizers, savings and loans for business capital, revolving funds, and gender education, cultivation of maize, composites, and devotions, while the object is a productive, creative economy model and women's independence in independent industrial areas the Rasau Jaya Transmigration area.

This research is in the form of a model implementation of a productive creative economy and women's independence based on CLAC. Data collection techniques through direct observation, distributing questionnaires, and in-depth interviews (Bogdan and Taylor, 1993). The research approach used was Development Research (Borg \& Gall, 1989), which began developing a productive, creative economy model and women's independence based on CLAC and continued with the model implementation stage.

\section{RESULT AND DISCUSSION}

\section{CLAC Women's Entrepreneurial Behavior as a Community Empowerment}

To study women's entrepreneurial behavior in CLAC Marga Jaya, researchers distributed questionnaires to CLAC members, especially 100 women from 6 villages in Rasau Jaya District. After the questionnaire was distributed, the following data were obtained:

\section{Want to Add Knowledge}

Most of the women who are members of CLAC have the awareness to always increase their knowledge, especially in the business sector. With the amount of experience, they have regarding how good entrepreneurship will make CLAC members increase productivity and business progress. Respondents 
answered that 42 people strongly agree (42\%) agree 28 people (28\%), doubt there are 11 people (11\%), 11 people disagree (11\%), and strongly disagree with 8 people (8\%). This can be seen in Table 4.1 below:

Table 2. Alternative Answer Options Want to Increase Knowledge

\begin{tabular}{|l|l|l|l|}
\hline No & Item & Amount & Percentage (\%) \\
\hline 1 & Strongly Agree & 42 & 42 \\
\hline 2 & Agree & 28 & 28 \\
\hline 3 & Doubtful & 11 & 11 \\
\hline 4 & Disagree & 11 & 11 \\
\hline 5 & Strongly Disagree & 8 & 8 \\
\hline & Total & 100 & 100 \\
\hline
\end{tabular}

Source: Processed, 2019

\section{Ambition to Move Forward}

Another positive attitude that CLAC Marga Jaya members have is that they have a firm purpose of moving forward. They believe that a business's progress needs to be based on a strong desire, without a strong ambition, an entrepreneur will not be able to achieve success. Strong ambition, must be balanced with hard effort and good self-discipline.

Respondents answered strongly agree that there are 40 people (40\%), agree 28 people (28\%), doubt 19 people (19\%), disagree 10 people (10\%) and strongly disagree 3 people (3\%). This can be seen in Table 4.2 below:

\section{Table 3. Alternative Answer Options Ambition to Move Forward}

\begin{tabular}{|l|l|l|l|}
\hline No & Item & Amount & Percentage (\%) \\
\hline 1 & Strongly Agree & 40 & 40 \\
\hline 2 & Agree & 28 & 28 \\
\hline 3 & Doubtful & 19 & 19 \\
\hline 4 & Disagree & 10 & 10 \\
\hline 5 & Strongly Disagree & 3 & 3 \\
\hline & Total & 100 & 100 \\
\hline
\end{tabular}

Source: Processed, 2019

\section{Have Confidence}

Believing in one's abilities is one of the keys to success in a business that is involved. CLAC women members have a reasonably good self-confidence in entrepreneurship. The greater the self-confidence, the better the resulting action. So that it is expected to produce success in entrepreneurship. Respondents answered strongly agree that there are 30 people (30\%) agree with 19 people (19\%), doubt 30 people (30\%), disagree with 12 people (12\%), and strongly disagree with 9 people (9\%). This can be seen in Table 4.3 below:

Table 4. Alternative Answer Options Have Confidence

\begin{tabular}{|l|l|l|l|}
\hline No & Item & Amount & Percentage (\%) \\
\hline 1 & Strongly Agree & 30 & 30 \\
\hline 2 & Agree & 19 & 19 \\
\hline 3 & Doubtful & 30 & 30 \\
\hline 4 & Disagree & 12 & 12 \\
\hline 5 & Strongly disagree & 9 & 9 \\
\hline & Total & 100 & 100 \\
\hline
\end{tabular}

Source: Processed, 2019

\section{Hard work}

Hard work is the capital for the success of an entrepreneur. Based on the results of the distribution of questionnaires conducted, it was found that women members of the CLAC believed in the importance of hard work in entrepreneurship so that most of them had a challenging working spirit. Every successful entrepreneur 
takes the real hard work of his business. Respondents answered strongly agree that there are 40 people (40\%), agree 32 people (32\%), doubt 18 people (18\%), disagree 3 people (3\%) and strongly disagree 7 people $(7 \%$.) can be seen in table 4.4. the following:

Table 5. Alternative Choice Answers Hard work

\begin{tabular}{|l|l|l|l|}
\hline No & Item & Amount & $\begin{array}{l}\text { Percentage } \\
\text { (\%) }\end{array}$ \\
\hline 1 & Strongly Agree & 40 & 40 \\
\hline 2 & Agree & 32 & 32 \\
\hline 3 & Doubtful & 18 & 18 \\
\hline 4 & Disagree & 3 & 3 \\
\hline 5 & Strongly disagree & 7 & 7 \\
\hline & Total & 100 & 100 \\
\hline
\end{tabular}

Source: Processed, 2019

\section{Collaboration with Others}

Collaboration with other people can be realized in a social environment as the first step to developing a business. An entrepreneur must be generous, comfortable to get along with, friendly, and liked by society and avoid actions that harm others. Women members of CLAC Marga Jaya are well aware of this, so they prefer always to work together to build a profitable business. Respondents answered strongly agree that there are 38 people (38\%), agree with 22 people (22\%), doubt there are 12 people (12\%), disagree with 18 people (18\%), and strongly disagree with 10 people $(10 \%)$. This can be seen in Table 4.5 below:

Table 6. Alternative Choice Answers to Cooperation with Others

\begin{tabular}{|l|l|l|l|}
\hline No & Item & Amount & Percentage (\%) \\
\hline 1 & Strongly Agree & 38 & 38 \\
\hline 2 & Agree & 22 & 22 \\
\hline 3 & Doubtful & 12 & 12 \\
\hline 4 & Disagree & 18 & 18 \\
\hline 5 & Strongly disagree & 10 & 10 \\
\hline & Total & 100 & 100 \\
\hline
\end{tabular}

Source: Processed, 2019

\section{Oriented to tasks and results}

The point is that an entrepreneur must have an attitude of responsibility for the tasks assigned to him and be responsible for the assigned tasks' results. Based on the questionnaire distribution results, it shows that CLAC members have the right attitude or awareness to be responsible for the tasks given to support good results. Respondents answered strongly agree that there are 58 people (58\%) agree there are 26 people (26\%), doubt there are 16 people (16\%), answer disagree there is no (0\%), and strongly disagree there is no (0\%). ). This can be seen in Table 4.6 below:

Table 7. Alternative Answer Options Task and result oriented

\begin{tabular}{|l|l|l|l|}
\hline No & Item & Amount & Percentage (\%) \\
\hline 1 & Strongly Agree & 58 & 58 \\
\hline 2 & Agree & 26 & 26 \\
\hline 3 & Doubtful & 16 & 16 \\
\hline 4 & Disagree & 0 & 0 \\
\hline 5 & Strongly disagree & 0 & 0 \\
\hline & Total & 100 & 100 \\
\hline
\end{tabular}

Source: Processed, 2019

\section{Risk Taker}


As a business actor, an entrepreneur will undoubtedly face choices where each choice that will be taken will have its consequences. One must have the courage to take risks and face any chances for the steps taken. The results of the questionnaire filled in did show that female members in CLAC dared to take risks on what they would decide. Respondents answered firmly that 22 people (22\%) agreed, 38 people (38\%) agreed, 36 people doubted (36\%), 4 people disagreed (4\%), and none answered strongly disagreed $0 \%$. This can be seen in Table 4.7 below:

Table 8. Alternative Risk Takers Answer Options

\begin{tabular}{|l|l|l|l|}
\hline No & Item & Amount & Percentage (\%) \\
\hline 1 & Strongly Agree & 22 & 22 \\
\hline 2 & Agree & 38 & 38 \\
\hline 3 & Doubtful & 36 & 36 \\
\hline 4 & Disagree & 4 & 4 \\
\hline 5 & Strongly disagree & 0 & 0 \\
\hline & Total & 100 & 100 \\
\hline
\end{tabular}

Source: Processed, 2019

\section{Leadership}

Leadership is needed to advance a business. A person will not become an entrepreneur if he cannot lead, either leading himself or teaching others. The questionnaire results also showed that female members of CLAC Marga Jaya had good leadership traits to advance the business they were running. Respondents answered strongly agree that there are 40 people (40\%) agree there are 41 people (41\%), doubt there are 18 people (18\%), disagree with 1 person (1\%), and strongly disagree $0 \%$. This can be seen in table 4.8 below

Table 9. Alternative Leadership Answers

\begin{tabular}{|l|l|l|l|}
\hline No & Item & Amount & Percentage (\%) \\
\hline 1 & Strongly Agree & 40 & 40 \\
\hline 2 & Agree & 41 & 41 \\
\hline 3 & Doubtful & 18 & 18 \\
\hline 4 & Disagree & 1 & 1 \\
\hline 5 & Strongly disagree & 0 & 0 \\
\hline & Total & 100 & 100 \\
\hline
\end{tabular}

Source: Processed, 2019

\section{Originality}

Original is not just following other people's products but having their own opinion. The uniqueness of an entrepreneur requires creativity and innovation in carrying out his duties. In terms of originality, members of CLAC are also aware of this and continue to try to maintain the identity of each product developed. Respondents answered strongly agree that there are 38 people (38\%) agree there are 29 people (29\%), doubt there are 19 people (19\%), do not agree there are 10 people $(10 \%)$ and strongly disagree $0 \%$. This can be seen in table 4.9 below

Table 10. Alternative Answers to Originality

\begin{tabular}{|l|l|l|l|}
\hline No & Item & Jumlah & Prosentase (\%) \\
\hline 1 & Strongly Agree & 38 & 38 \\
\hline 2 & Agree & 29 & 29 \\
\hline 3 & Doubtful & 19 & 19 \\
\hline 4 & Disagree & 10 & 10 \\
\hline 5 & Strongly disagree & 4 & 4 \\
\hline & Total & 100 & 100 \\
\hline
\end{tabular}

Source: Processed, 2019

\section{Future-Oriented}


A business is not established for a while but is expected for a very long period. In this case, the continuity must be maintained. The view must be directed far in the future. An entrepreneur will prepare a plan and a mature strategy, clearly the steps to be implemented. The connection with the planning of members in CLAC also has a plan that will be carried out in the future to keep a business standing. Respondents answered strongly agree that there are 39 people (39\%), agree there are 39 people (39\%), doubt there are 22 people (22\%), disagree not there $(0 \%)$ and strongly disagree also not there $(0 \%)$. This can be seen in the following table 4:10:

Table 11. Future-Oriented Alternative Answers

\begin{tabular}{|l|l|l|l|}
\hline No & Item & Amount & Percentage (\%) \\
\hline 1 & Strongly Agree & 39 & 39 \\
\hline 2 & Agree & 39 & 39 \\
\hline 3 & Doubtful & 22 & 22 \\
\hline 4 & Disagree & 0 & 0 \\
\hline 5 & Strongly disagree & 0 & 0 \\
\hline & Total & 100 & 100 \\
\hline
\end{tabular}

Source: Processed, 2019

From the 10 items related to the entrepreneurial behavior of women members of the Marga Jaya CLAC group, it can be concluded that most members of the CLAC women's group are very enthusiastic about the existence of entrepreneurship education as a means for them to be able to lift the family economy. The desire to increase knowledge, ambition to progress, hard work, and future orientation reflects the group members' willingness to be independent.

\section{Creative Economy Education as a Form of Women's Independence}

Women and the economy are two things that are currently difficult to separate. As stated in the report "Creative Economic Workers" released by the Creative Economic Agency (Bekraf). There, it is stated that women are currently the leading players in Indonesia's creative industry from 2011 until the economic census was carried out in 2016. With a workforce figure of $53.86 \%$ and a business ownership rate of $54.96 \%$. They are an active group because they dare to take initiatives in economic development to improve family welfare. Also, women entrepreneurs tend to be more professional. Women have the potential to develop family entrepreneurship towards a creative economy.

Entrepreneurial women are also considered to be more responsible and professional in managing finances. The government and banks have also supported entrepreneurs and entrepreneurs by providing financial access. This access is expected to provide opportunities for entrepreneurs to develop their businesses. According to Mayoux (2001), five main elements need to be considered in the process of empowering women, namely, as follows.

1. Welfare (Welfare), this aspect can be said to be one of the crucial elements in increasing women's empowerment. It cannot be denied that in access to welfare, women are in a disadvantageous position.

2. Access is defined as women's ability to obtain rights/access to productive resources such as land, credit, training, marketing facilities, labor, and all public services equal to women.

3. Conscientization (Konsientisasi), understanding the differences in gender roles and gender roles.

4. Participation, equality of the involvement of women in decision-making, policy-making, planning, and administration processes. This participation refers to women's equal representation in decisionmaking structures both formally and informally, and their voice in policy formulation affects their society.

5. Equality of Control (Equality in power), equality of power over factors of production, and distribution of profits so that both women and men are in a dominant position.

Women in the Rasau Jaya district, Kubu Raya Regency, can develop entrepreneurship towards a creative economy. Some of these potentials include:

a. Development of the "Bapak Angkat" work pattern carried out by local entrepreneurs in accommodating women's creative economic business activities;

b. Strengthening networks between women entrepreneurs and local entrepreneurs, significantly to increase business turnover and product quality; 
c. Developing a "learning by doing" work culture (learning by doing) among women entrepreneurs with local entrepreneurs, so that they can learn from one another, exchange information and skills, and strengthen one another;

d. Building a climate of togetherness in work, so that mutual motivation appears to develop a business;

e. Building creativity in some businesswomen, and this creativity is transmitted to fellow women entrepreneurs.

Besides the potential they have, there are also creative economic entrepreneurial opportunities developed by women in Rasau Jaya District, Kubu Raya Regency. These opportunities are expected to contribute to developing the creative economy to improve the family economy, while these opportunities include:

a. there is already a widely developed agricultural business in the Kubu Raya district and its surroundings;

b. ornamental plant business has grown which has penetrated the area of Kubu Raya Regency;

c. various kinds of handicrafts that have the potential to be developed as souvenirs have been developed;

d. There has been the development of working groups that process household waste into fertilizer

e. biogas development business has been developed through the use of livestock manure;

f. has developed a variety of traditional foods as typical local snacks.

In addition to the potential and opportunities, there are still obstacles in developing women's entrepreneurship in realizing the creative economy, these obstacles include:

1. The majority of women entrepreneurs have limited knowledge.

2. The majority of women entrepreneurs have soft skills to develop the creative economy.

3. Most women entrepreneurs are limited in working capital for the development of production tools.

4. The majority of women entrepreneurs have limited access to information, capital, and market potential.

To address the potentials, opportunities, and obstacles in entrepreneurship development, a creative economy-based non-formal entrepreneurship education can be held by utilizing the Marga Jaya Community Learning Activity Center (CLAC) forum. Participation is an opportunity for women to change their family status, primarily through investment in education that can provide additional income opportunities such as improving skills through non-formal education at the Community Learning Activity Center (CLAC).

CLAC non-formal education was born as an alternative to the limitations of the education system in formal education institutions, such as the lack of relevance of educational materials to community needs, lack of flexibility, and relatively large financing and infrastructure needs (Sudjana, 2004). According to Sudjana, education such as skills education is considered to have several advantages, including relatively cheaper costs because education programs are carried out in a relatively short time to meet specific learning needs.

In addition to having a level of relevance to learning materials, CLAC programs are held based on students' needs, the needs of the community, and to meet the needs of the institutions where students work. There is a close relationship between the content of education programs and the world of work; learning activities are not separated from work activities or students' functioning in the community. Non-formal education programs provide relatively faster returns to students and graduates compared to formal education programs.

The participation of CLAC Marga Jaya in providing creative economy education can be done in the form of participation-based skills education. Participation-based skills education is carried out based on the steps that have been formulated in planning, which include identifying learning needs, formulating goals, and compiling learning materials about the creative economy. Implementation is the implementation of the entire planned learning process. In this case, the materials, methods, learning facilities, and time needed are determined according to the needs of skills education to get optimal learning opportunities and experiences.

Forming study groups is one of the pre-education learning strategies that aim to increase student participation through educational communication. The communication process can be created more effectively through study groups that are not too large in number. Study groups serve as both a method and a medium for making changes. Skills education models like this can be said to be successful because of the active participation of students. Participatory skills education in CLAC has its uniqueness because, in addition to mastering skills, it is also socialized to group members to form ethics in group life.

It is hoped that the existence of entrepreneurship education through the creative economy empowerment model for women members of the Marga Jaya CLAC group, Rasau Jaya District, can impact the 
family, especially in terms of economic improvement. This is in line with the development strategy in the Kubu Raya Regency, namely in economic development and human resources.

\section{CONCLUSION}

The potential for product development for the business group under the guidance of CLAC Marga Jaya is still very wide because the local resources owned by the Rasau Jaya District are very diverse. Of the 10 items related to the behavior of women in entrepreneurship CLAC, most of them strongly agree, which shows that there is entrepreneurship education as a means for them to be able to lift the family economy. The desire to gain knowledge, ambition to progress, hard work, and future orientation reflects the willingness of the group members to be independent.

Through a creative economy empowerment model, entrepreneurship education programs can be carried out through non-formal education at the Community Learning Activity Center (CLAC). This non-formal education is carried out as an alternative to the education delivery system's limitations informal education institutions, such as the lack of relevance of educational materials to community needs, lack of flexibility, and relatively large financing and infrastructure needs. The method that can be applied to Entrepreneurship Education through the creative economy empowerment model is participation-based skills education making it easier for women to understand and apply what they have learned.

\section{REFERENCES}

Alcalde, M. C. (2010). The woman in the violence: Gender, poverty, and resistance in Peru. Vanderbilt University Press.

Anthopoulou, T. (2010). Rural women in local agrofood production: Between entrepreneurial initiatives and family strategies. A case study in Greece. Journal of rural studies, 26(4), 394-403.

Azariadis, C., \& Stachurski, J. (2005). Poverty traps. Handbook of economic growth, 1, 295-384.

Basuki, A., \& Prasetyo, Y. E. (2007). Memusiumkan Kemiskinan. Surakarta: PATTIRO Surakarta.

Borg, W. R., \& Gall, M. D. (1989). Educational Research; An Introduction. New York, NY: McKay and Company.

BPS. (2014). Data Strategis BPS. Badan Pusat Statistik. Jakarta.

Dodd, F. (2012). Women leaders in the creative industries: a baseline study. International Journal of Gender and Entrepreneurship.

Fatimah. (2006). Mengapa Perlu anggaran Responsif Gender, Journal of Women. ISSN : 1410-153

Hackett, G., \& Betz, N. E. (1981). A self-efficacy approach to the career development of women. Journal of vocational behavior, 18(3), 326-339.

Hariadie, \& Djusmartinah, R. (2013). Ekonomi Kreatif Dalam Upaya Pemberdayaan Masyarakat KampungKampung Kota di Kecamatan Gayungan. PGRI Surabaya

Hulme, D., \& Shepherd, A. (2003). Conceptualizing chronic poverty. World development, 31(3), 403-423.

Hutajulu, J. P. (2015). Analisis Peran Perempuan dalam Pertanian di Kecamatan Rasau Jaya Kabupaten Kuburaya. Jurnal Social Economic of Agriculture, 4(1), 23060.

Ismail, S. E. K. I. (2019). 11 Women's Empowerment and Regional Development in the Context of Creative Economy Approach. Women's Economic Empowerment in Turkey, 143.

Jackson, C. (1996). Rescuing gender from the poverty trap. World development, 24(3), 489-504.

Joekes, S. P. (Ed.). (1990). Women in the world economy: an INSTRAW study. Oxford University Press.

Loekman, S. (1995). Substansi Permasalahan Kemiskinan dan Kesenjangan. On Dewanta (ed), Kemiskinan dan Kesenjangan di Indonesia. Yogyakarta. Aditya Medi.

Marwanti, S., \& Astuti, I. D. (2012). Model pemberdayaan perempuan miskin melalui pengembangan kewirausahaan keluarga menuju ekonomi kreatif di Kabupaten Karanganyar. Sepa, 9(1), 134-144.

Mastuti, S. (2006). Model Alternatif Penerapan Anggaran Responsif Gender. Jurnal Perempuan. ISSN : 1410153.

Mayoux, L. (2001). Gender Equity, Equality, and Women's Empowerment. Principle, and Development.

McLanahan, S. S., \& Kelly, E. L. (2006). The feminization of poverty. In Handbook of the Sociology of Gender (pp. 127-145). Springer, Boston, MA. 
Miles, M. B. \& Huberman, A. M. (1985).Qualitative Data Analysis: A Sourcebook of NewMethods. London: Sage Publications.

Moser, C. O. (1989). Gender planning in the Third World: meeting practical and strategic gender needs. World development, 17(11), 1799-1825.

Neysmith, S. M., \& Reitsma-Street, M. (2005, September). "Provisioning": Conceptualizing the work of women for 21st century social policy. In Women's Studies International Forum (Vol. 28, No. 5, pp. 381-391). Pergamon.

Pattiro Borg, W., \& Gall. (1989), Educational Research Introduction, New York.

Potts, J. (2009). Why creative industries matter to economic evolution. Economics of innovation and new technology, 18(7), 663-673.

Poutanen, S., \& Kovalainen, A. (2017). Gender and innovation in the new economy: women, identity, and creative work. Springer.

Ravallion, M. (2007). Evaluating anti-poverty programs. Handbook of development economics, 4, 3787-3846.

Saludung, J. (2009). Evaluasi Keterlibatan Perempuan Dalam Program Pkbm Di Makassar (Analisis Gender Pada Studi Kasus Di Tiga PKBM: PKBM Anggrek Capoa, PKBM La Galigo, Dan PKBM Toddopuli).

Sarkis, J., Naser, K., Mohammed, W. R., \& Nuseibeh, R. (2009). Factors that affect women entrepreneurs: evidence from an emerging economy. International Journal of Organizational Analysis.

Setyaningsih, S., Rucita, C. P., Hani, U., \& Rachmania, I. N. (2012). Women empowerment through creative industry: a case study. Procedia Economics and Finance, 4, 213-222.

Subiyantoro, E. P. (2005). Perempuan Miskin di Ujung Negeri. Jurnal Perempuan. ISSN: 1410-153x.

Sullaida, N., \& Ahyar, C. (2017). The development of an independent entrepreneurship model through creative economy for women in Lhokseumawe city. Proceedings of MICoMS, 87-92.

Tsui, K. Y. (2002). Multidimensional poverty indices. Social choice and welfare, 19(1), 69-93.

Wardoyo.Tanpa tahun.Kewirausahaan (Online).http://wardoyo.staff.gunadarma.ac.id. Access on Thursday 12 July 2012.

Woldie, A., \& Adersua, A. (2004). Female entrepreneurs in a transitional economy. International journal of social economics.

Yuli Indrawati Sari, 2003, Perempuan dan Pengambilan Keputusan dalam Good Governance Proyect- Studi kasus : Program Pengembangan Kecamatan di Pamanukan Sebrang Jawa Barat, Jurnal Analisis Sosial, Vol 8 No.2 October 2003, ISSN 1411-0024. Page 129-139

Yurisinthae, E., \& Dolorosa, E. (2015). Analisis Penentuan Sektor Unggulan Perekonomian di Kabupaten Kubu Raya. Jurnal Ekonomi Bisnis dan Kewirausahaan, 4(2), 253-269. 